\title{
Indegenous Healer Knowledge About Illness and The Way to Make Traditional Medicine
}

\author{
Regina Marintan Sinaga, Fikarwin Zuska and Panal Sitorus \\ Sekolah Pascasarjana, Universitas Sumatera Utara, Medan, Indonesia \\ Reginasinaga52@gmail.com
}

\begin{abstract}
Key Words: Indegenous Healer, The Guidelines for Good Traditional Medicine Manufacturing Practices /CPOTB, Personalistic Medical System, Naturalistic Medical System, Traditional Treatment Practices.

Abstract: $\quad$ This study discusses the knowledge of traditional healers about disease healing techniques and how to make good traditional medicines. The purpose of this study was to describe the knowledge of traditional healers about disease healing techniques and how to manufacture traditional medicines in traditional medicine systems in Medan City. The research method used in data collection is observation and in-depth interviews. The result of this research is that the knowledge of traditional healers about disease healing techniques is a combination of a personalistic medical system and a naturalistic medical system. Knowledge about how to make good traditional medicine (CPOTB) is only based on traditional knowledge (indegenous knowledge) which is still far from quality standards in health services. maximum.
\end{abstract}

\section{INTRODUCTION}

This study examines the views of traditional healers about the practices carried out in traditional medicine using medicinal plants in the form of herbs and also by using animals which are believed by healers to cure various types of diseases. Knowledge and skills about these medical practices are obtained based on experiences received from family or relatives, who carry out these traditional medicine activities and have continued to the present day

Indonesian people have long recognized and used medicinal plants as an effort to overcome health problems. The use of medicinal plants, partly based on experience and skills from generation to generation, is passed on from generation to generation (Sari, 2006). Others are obtained by learning from those who know.

The use of plant materials, both as medicine and as maintenance and health improvement, has recently tended to increase, especially with the issue of bact to nature. In addition, the high prices of modern medicines also encourage some people to prefer to use traditional medicinal plants (Katno et al., 2008).

Although modern health services have developed in Indonesia, the number of people who use traditional medicine is still high. According to National Economic Census (2001), as many as $31.7 \%$ of Indonesians use traditional medicine and $9.8 \%$ seek treatment in traditional ways to overcome their health problems. The World Health Organization (WHO, 2003) recommends the use of traditional medicines including herbs in public health maintenance, prevention and treatment of diseases, especially for chronic, degenerative and cancer diseases.

People in the modern era do not fully believe in scientific medical treatment. Each group of people who believe in medicine and alternatives has different good in between. In truth today, the development of modern medical medicine practices both within government and private institutions is always accompanied by traditional medicine practices. This is because traditional language still lives as an alternative model in society (Fanani, 2014).

Traditional people's knowledge of the medicinal properties of a plant for the healing of a disease is generally based on natural cues or animal behavior. For example, a heart-shaped leaf has a clue that it can cure liver disease; yellow parts of plants such as turmeric and "temulawak" have clues to cure jaundice; sick animals that eat certain types of plants give instructions that the plant is medicinal (Supriadi, 2005).

Today plant-based treatments have been widely accepted in almost all countries of the world. According to the World Health Organization (WHO), countries in Africa, Asia, and Latin America use plant-based medicines (herbs) as a complement to the primary treatment they receive. 
Even in Africa, as many as $80 \%$ of the population uses herbal remedies for primary treatment. WHO also supports various efforts to improve the safety of the use of traditional medicines (WHO 2003). The things that are driving the increase in the use of plant-based medicines in developed countries are in addition to the search for alternative treatments because the results achieved by modern medicine are considered not always satisfactory, also because the reputation of traditional medicine is improving around the world (Sukandar, 2006).

The World Health Organization or WHO on the use of traditional medicines is considered safer than the use of modern medicines. This is because traditional medicine has relatively few side effects compared to modern medicine. However, it does not mean that traditional medicines have no side effects, if their use is inappropriate (Katno et al., 2008). Likewise, the assumption that traditional amna medicine is consumed even though the symptoms of illness have disappeared. This assumption is wrong, to some extent, it may be true, but if it has exceeded the limit it can be dangerous (Sari, 2006). For example in Belgium, there are 70 people who have to undergo dialysis or kidney transplants due to consuming slimming from the wrong plant (WHO, 2003).

Another example of the side effects of using medicinal plants is the use of dringo (Acorus calamus L), which is commonly used to treat stress. This dringo plant has similar properties to the amphetamines and ecstasy. Low doses of dringo have a relaxing effect on muscles and have a sedative (sedative) effect on the central nervous system. When used in high doses, dringo has the opposite effect, namely, increasing mental activity (psychoactivity). Based on these scientific facts, the United States Federal Drugs of Administration (FDA) has banned the use of dringo internally, because it causes more harm than good (Sari, 2006).

Data on the profile of Traditional Medicine in North Sumatra Province shows that there are 2629 traditional healers using traditional medicines / ingredients, derived from medicinal plants that are concocted by themselves or Indonesian traditional medicines. Including Medan City as many as 739 people (Health Office of North Sumatra Province, 2005). This shows that there are still many people in Medan City who use traditional medicinal plants through traditional medicine to improve (promote), maintain (rehabilitative) health, prevent disease (preventive) and treat diseases (curative).

Likewise, the research conducted by researchers on the study of traditional medicinal practices was inspired, among other things, by the fact that people around Medan City and from outside areas still use traditional medicine to overcome their health problems. Whereas the knowledge of traditional healers about plants that are part of medicine, includes the selection (parts) of plants, how to wash plants and the tools used, water used to wash medicinal plants, drying, how to mix, according to researchers that these practices have not met the requirements. as stated in the Guidelines for Good Traditional Medicine Manufacturing Practices (CPOTB) (BPOM RI, 2006).

The Guidelines to Make Good Traditional Medicines (CPOTB) is a regulation of the Head of the Indonesian Food and Drug Supervisory Agency (BPOM), aimed at protecting the public against things that can harm health, so it is necessary to prevent the circulation of traditional medicines that do not meet quality, safety and benefit requirements. for the wearer. (BPOM RI, 2006).

This can cause diseases such as diarrhea due to bacterial contamination from water (which is of poor quality) for washing medicinal plants and / or the equipment used is not clean (does not meet the requirements). Then the time period for using processed traditional medicinal plants (jamu) is also not determined. This could allow the presence of aflatoxin toxins in herbal preparations. These toxins have the potential to cause cirrhosis and liver cancer (Sirait, 1994). In addition, the dose used for usage using inaccurate measurements, such as a handful, a handful, etc., can reduce the safety assurance of traditional medicine (Sari, 2008). Furthermore, healing techniques in dealing with sick people are a part that needs to be known according to the concepts of traditional medicine practiced by traditional healers.

Medication efforts / activities and the provision of traditional medicines as mentioned above have been going on for a long time. Its development is running fast and widespread in various levels of society in various regions. The spread of traditional medicine is not limited by administrative boundaries so that its existence continues to expand beyond administrative boundaries and levels of society.

From the facts mentioned above, this study was conducted. This study examines the knowledge of traditional healers in traditional medical practices, which includes knowledge of disease healing techniques and ways of making traditional medicines.

\section{RESEARCH METHOD}

This study of traditional medicine uses qualitative research with the method of observation (observation) in the field of activities that occur in the research location, as well as in-depth interviews with traditional healers. This research was conducted 
to find out the explanation (explants) of the object of research (the explanandum), namely the knowledge of making traditional medicine and healing techniques.

The research was conducted in Medan City on the grounds that in Medan there are still many traditional healers who carry out traditional medicinal practices using traditional medicinal plants / jamu. It can be seen, among others, that the traditional herbal medicine includes gurah, healer, shinshe, aromatherapist and oukup. In addition, there are also traditional skill healers, including traditional massage therapists, traditional healers for fractures, and traditional healers for circumcision.

Observations and interviews by researchers were carried out in the areas of Medan Tuntung and Medan Baru City, regarding the doctors who happened to have been practicing traditional medicine for about 40 years.

The key informants in this study were 3 people, namely a traditional practitioner who has been practicing medicine for 40 years and incidentally is close to where I live as a researcher; then the families of the traditional healers are like children, brothers, sisters; and also patients of traditional Healer.

\section{RESULT AND DISCUSSION}

\section{Indegenous Healing Knowledge about Traditional Healer}

Knowledge and skills of traditional healers about traditional medicinal herbs were obtained from the direct experience of practicing traditional medicine at a very young age, by helping to make traditional medicinal herbs with parents, then learning and gaining knowledge through suffering (illness) themselves.

The initial stage of knowledge about medicine begins with introducing the types of medicinal plants used in medicinal practices. For example, tamarind seeds are used as a medicine for high blood pressure, stroke and colds. This knowledge is getting better when traditional healers gain experience from treating their own diseases who also use traditional medicine.

Medicines sourced from animals can also be used to treat various diseases, for example, bile from cattle and goat is used to treat heart disease or it can also be used as prevention or heart strengthening and this knowledge is also obtained from the parents of traditional healers.

Sources of various kinds of medicinal plants used are obtained from traditional markets such as Pancur Batu, Sambu and also obtained from other areas such as the forests of Berastagi, Kabanjahe,
Dairi and its surroundings. The material obtained from such a difficult place (forest) is taken by someone who is believed to have special abilities such as the "sixth sense". According to the informant, Mrs. Ati, it is believed that the medicinal plant with this ability can provide guidance through the "sixth sense" to medicinal plants or animals that will be used as ingredients in medicinal herbs in treating diseases.

\section{Indegenous Healing Knowledge about the way to make Traditional Healer (Medicinal Herbs)}

Some of the healers interviewed by researchers said that knowledge about medicinal herbs was obtained from parents and relatives, also obtained from books about medicinal plants. Furthermore, studied then combined with traditional knowledge (indegenous knowledge) that they have acquired from generation to generation.

To obtain information about traditional medicine knowledge about how to make medicinal herbs, the researcher obtained from 2 informants, namely Iting and Mrs. Ati, while Mrs Imah, the researcher could not get the data because she did not want to tell it.

Plant ingredients for medicinal herbs in the form of plant parts such as roots, stems, leaves, flowers, fruit, all of which can be used for medicinal herbs. If any part of the plant is not used for one type of medicinal herb, the unused plant material, such as orange peel, can be used as an ingredient for a mixture of medicinal herbs. Knowledge of the age of the plant, the selection of plant materials used is not an important part to be prepared. But they know that a good plant to be used as a medicinal herb should be old.

The ingredients for medicinal herbs purchased from the market or from the forest are simply placed on the floor without wearing a base. This has the potential for contaminants such as dust and sand, and if no sorting (separation) is carried out between medicinal plants and contaminants, the medicinal ingredients will be contaminated. This pollution will affect the quality of medicinal ingredients products which can be detrimental to health.

Washing of plant material is carried out only once using water from a water storage tank, where the water used is also for daily activities. This indicates that the water used for washing plant material is not clean.

Talking about how to make medicinal herbs is a very difficult thing to do. There was an impression of discomfort from the mediciners when researchers asked about the ways of making drugs, starting with washing the ingredients to become ingredients for medicinal herbs. Thus, more researchers obtained data on activities for the manufacture of medicinal herbs from observations. Likewise, the tools used for 
drug preparation activities that the researchers observed looked less clean.

Then in mixing the medicinal ingredients, one of the informants, Iting, will stir the ingredients by hand, regardless of whether his hands are free from contamination. For plants that have not been used, then Mrs. Ati expands to expose them to direct sunlight which will affect the effectiveness of these plants. From the observations of researchers, the plant material is dried in the sun on thick plastic and left alone so that some chickens will scavenge the dried plants.

For ready-made medicinal herbs, the usage limit is not certain, according to Iting, the ingredients used can usually last up to 2 months. But from the observations of the researchers, when the Iting informant dried the herbs to take, there was Indong in them. Indong by Iting is a type of mold found in traditional ingredients. Mold exists when the traditional medicinal ingredients used exceed the specified time limit. From a health perspective, this is dangerous because it can cause cirrhosis and liver cancer (Sirait, M., 1995).

Meanwhile, the size / dose of plant material used when making medicinal herbs based only on experience and also relying on the memory of the doctor (not writing in the book) will affect the efficacy of the medicinal ingredients. . So that in practice, when viewed from a point of view, the way of making good traditional medicines is still far from the standard of quality in maximum health services.

\section{Indegenous Healing knowledge about Healing Illness Technique}

According to Foster and Anderson (1978) healing techniques in all health systems are based on beliefs about the occurrence of disease, which is called the etiology of illness. The etiology of disease is divided into (1) personalistic etiology and (2) naturalistic etiology.

Likewise, with the healing technique by the Iting informant, which classifies the types of diseases into 2 parts, namely fractures, sprains, heartburn, child fever, children not having an appetite, children catching colds, impotence, high blood pressure, heart disease, Diabetes, which is called the naturalistic medical system, and diseases that are transmitted through "agents", namely ghosts or witchcraft diseases, are called the personalistic medical system. For the method of treating the Iting informant for various diseases, it was done by "tapping" (the act of touching by massaging or massage) with his left hand, both for external and internal diseases.

Then, in determining what treatment to take for each patient, the Iting informant obtained through the 'nipi' (dream). In this dream, he has a dialogue with the parents who come to him and tell the patient what medication and medicines are being used.

In Foster and Anderson (1989) a traditional healer makes a diagnosis of the factors that cause disease. He will use his magical powers to heal patients who are sick due to personalistic factors. Or, using certain techniques and ingredients for those affected by naturalistic factors.

Meanwhile, the information of informant Ati, the treatment technique that he did, for example for the treatment of patients with broken bones, "After the wound is cleaned with clean water, then covered with sterile gauze, then stick to fresh yellow, wait for 3 days, if there is pus it means that the wound is less. clean, so it needs to be cleaned again if necessary smeared with betadin and then made again like the original way. Usually before treating patients, he performs prayers first, asking God to do the treatment properly and correctly so that patients can be treated and recovered.

Then according to the informant Mrs Imah that she practiced medicine besides using a mixture of plant ingredients as well as doing traditional medicine by increasing her knowledge by following modern health training and through books related to modern health.

Based on the results of the research that has been done, it is found that the knowledge of traditional healers in treating diseases begins with diagnosing the disease through sequences or tapping and then by taking a sufficient bath which is useful for improving blood circulation and is also intended so that drug absorption can work properly. Then, knowledge about how to make medicinal ingredients used in medicine which includes the process of drying the plant material, washing the plant material, the equipment used, the size / measurement used, as well as the useful life of the medicinal ingredients used have not met the health service requirements maximally. In carrying out traditional medical practices must also be supported by adequate facilities and means so that treatment can provide better and professional services and can be sustainable until in the future.

\section{CONLUSION}

The conclusion of this study of traditional medicine knowledge is about the knowledge of diseases, how to treat diseases and how to make traditional medicinal herbs, carried out by traditional medicine practitioners and also people who are in the treatment environment. The practice of traditional medicine has been going on for quite a long time, inherited through parents, relatives and also obtained by studying books on diseases and 
traditional medicinal herbs. Understanding of the ingredients of plants to be used for traditional medicinal herbs, known from parents and relatives by engaging directly through the practices of making traditional medicine. The involvement becomes the main capital (main capital) which is very important to know a number of types of medicinal plants. They learned the properties of each type of plant, also studied over a mixture of several kinds of plants used as medicinal herbs to cure various diseases. Knowledge of medicinal plants has become a part of their lives, especially in tackling their own health problems. And the plants used generally also they know well. Knowledge of traditional medicine in treating diseases begins with diagnosing the disease through sequence or precipitation and furthermore by doing a bath oukup useful to facilitate blood circulation is also intended so that the absorption of the drug can work properly. Knowledge of how to make medicinal herbs used in medicine that includes the process of drying plant materials washing plant materials, equipment used, size / measure used, also the life of the medicinal herbs used have not met the requirements of health services to the maximum. Knowledge of various types of diseases, based on diseases caused by changes and discrepancies that occur in the body. These changes and discrepancies can be seen from natural symptoms such as wind, heat, cold, and also associated with one of the veins called the naturalistic medical system. While the type of disease outside the symptoms of nature, is caused by the existence of "agents" (intermediaries) namely the influence of the forces of subtle beings and supernatural forces called the medical system of personality

\section{REFERENCES}

Anderson, (1986). Health Anthropology. UI Press. Jakarta, Cetakan Pertama.

BPOM Republik Indonesia. (2006) Pedoman Cara Pembuatan Obat Tradisional Yang Baik, https://www.pom.go.id/new/files/pedoman/Pedo man CPOB 6.pdf diakses Desember 2020

Dinas Kesehatan Propinsi Sumatera Utara. 2005. Profil Pengobatan Tradisional di Propinsi Sumatera Utara.

Fanani, S., \& Dewi, T. K. (2014). Health belief model pada pasien pengobatan alternatif supranatural dengan bantuan dukun. Jurnal psikologi klinis dan kesehatan mental, 3(1), 5459.

Foster G. \& Andersen B. 2008. Antroppologi Kesehatan. Terjemahan Priyanti Pakan Suryadarma \& Meutia F. Swasono. UI Press. Jakarta.
Katno., Pramono, S. 2008. Tingkat Manfaat dan Keamanan Tanaman Obat dan Obat Tradisional. Balai Penelitian Obat Tawangmangu. Fakultas Farmasi UGM. Yogyakarta.

Sari, L, O, R, K. 2006. Pemanfataan Obat Tradisional dengan Pertimbangan Manfaat dan Keamanannya. Majalah Ilmu Kemarfasian. Universitas Jember.

Sirait, M. 1995. Laporan Tim Analisa dan Evaluasi Hukum tentang Perlindungan dan Pengawasan terhadap Pemakaian Obat Tradisional. Jakarta.

Sukandar E Y, (2006). Tren dan Paradigma Dunia Farmasi, Industri-KlinikTeknologi Kesehatan, disampaikan dalam orasi ilmiah Dies Natalis ITB

Supardi, S., \& Notosiswoyo, M. (2005). Pengobatan sendiri sakit kepala, demam, batuk dan pilek pada masyarakat di Desa Ciwalen, Kecamatan Warungkondang, Kabupaten Cianjur, Jawa Barat. Majalah Ilmu Kefarmasian, 2(3), 3.

Survei Sosial Ekonomi Nasional (SUSENAS) Kor, 2011

World Health Organisation (WHO), 2003, Traditional Medicine. https://www.who.int/intellectualproperty/topics/t raditional/en/ 